\title{
Easing the Transfer of Students from College to University Programs: How Can Learning Outcomes Help?
}

\author{
Irene Carter \\ James Coyle \\ Donald Leslie \\ University of Windsor
}

\begin{abstract}
Increasingly, students are seeking transfer from college to university educational programs. This challenges universities to assess the effectiveness of transfer policies and also challenges colleges to prepare students for continued education. This paper reviews the various transfer procedures used by Canadian universities, barriers experienced by students seeking transfer, and strategies for improving the transfer process. The authors propose the use of learning outcomes, which identify student knowledge and skills following an educational experience, to develop block transfer strategies that ease student transfer between educational programs.
\end{abstract}

\section{RÉSUMÉ}

Les étudiants cherchent de plus en plus à transférer leurs projets d'études collégiales vers un programme universitaire. Les universités doivent donc relever le défi d'évaluer l'efficacité de leurs politiques de transfert, tandis que les collèges doivent réfléchir sur la façon de mieux préparer leurs étudiants aux programmes de formation continue. Le présent article passe en revue les diverses procédures utilisées par les universités canadiennes, les obstacles que doivent surmonter les étudiants cherchant à effectuer un transfert et les stratégies d'amélioration du processus de transfert. Les auteurs proposent l'utilisation de résultats d'apprentissage, qui identifient les connaissances et les compétences acquises par les étudiants d'un programme donné, afin d'élaborer des stratégies générales qui faciliteront le transfert d'étudiants entre programmes éducatifs. 


\section{INTRODUCTION}

Students are increasingly entering university following coursework in college programs. This requires detailed policies for transferring college credits to the university course of study. There are many methods for accomplishing this. They include comparing college courses with current university courses on a student-bystudent basis, developing articulation agreements that determine credit transfer for specified college courses, applying provincial transfer criteria, and using block transfers that allow advanced placement in a university program. Unfortunately, these policies vary widely between institutions and are often implemented inconsistently.

According to the National Center for Education Statistics in the United States, about $40 \%$ of all post-secondary students change institutions at least one time in their academic careers (Miller, 2007). Many students choose college over university when beginning their post-secondary education because they consider colleges to be a stepping-stone to a university-level education. Colleges offer cheaper tuition costs, and are often closer to home (Andres, 2001; Cohen, 2005). College entrance GPA requirements are lower than those of universities, and there are opportunities for part-time study that are often not available in university programs.

When transfer rates are compiled across US and Canadian institutions of higher education, they vary from $45 \%$ to $80 \%$ (Cohen, 2003; Cohen 2005). Criteria that explain this range of transfer rates are primarily related to which comparisons are measured and who conducts the calculations. For example, phrasing questions by asking how many students aspire to higher education versus how many students are on the path to successful transfer may inflate the statistics. Transfer rates are higher in areas that view colleges as being feeder schools for universities and are lower in regions that still use the label of "technical schools" or "technical colleges" or when colleges are located at significant distances from universities. The opinions and perceptions of staff also influence rates. Schools that view transfer as a high priority and have current and easily accessible transfer information have much higher rates (Cohen, 2003; Cohen, 2005). The Council of Ministers of Education, Canada (CMEC, 2009) has encouraged strategies that improve transfer between post-secondary schools and reported provincial rates of students transferring between post-secondary institutions such as $20 \%$ in British Columbia (Student Transitions Project, 2008) and 25\% in Alberta (Alberta Council on Admissions and Transfer, 2010). An Ontario study of student transfer (Decock, 2004) indicated that $23 \%$ of students who complete programs at colleges of applied arts and technology intend to continue education at universities and $26 \%$ of students enrolled in universities have attended other post-secondary schools.

This paper reviews methods used to transfer course credit between postsecondary schools, identifies the challenges faced by students transferring from college to university, considers practices that attempt to remove barriers to admission, and proposes a learning-outcomes approach for improving the transfer process. Information about transfer policies and methods were reviewed by exam- 
ining the transfer requirements from Canadian university websites, reports and transfer information provided by provincial and federal ministries of higher education, and publications listed in the Educational Resources Information Center (ERIC). ERIC was also used to review analysis and studies of learning outcomes. This was supplemented by publications recommended by teaching and learning colleagues and manuscript reviewers.

\section{TRANSFER METHODS}

Universities use four types of transfer policies: evaluation of specific course credits, articulation agreements, province-wide transfer guides, and block transfers. Since evaluating college transcripts for a course-by-course transfer of credit is cumbersome, educational institutions have developed a number of methods for making transfers easier. Articulation agreements attempt to ease transfer between specific educational programs. Articulation is "the process of formally defining how course credit and/or programs earned at one institution will be applied towards credit and/or a degree from another institution" (Thompson, 2003). This defines a predictable transfer outcome. Since articulation agreements only apply to specific schools or programs, broader applications have been suggested. For example, Knoell (1996) recommended a collaborative model of articulation which involves creating a state-wide common course numbering system for all US colleges and universities; use of a portfolio for non-traditional transfer students; and wider collaboration between colleges, universities, and also employers who hire students.

British Columbia and Alberta have developed province-wide systems of transfer agreements between colleges and universities in order to reduce transfer barriers. A provincial council works to maximize student mobility between institutions, ensures that students do not have to repeat courses previously granted, and facilitates open communication and information exchange between all provincial post-secondary institutions (British Columbia Council on Admissions and Transfer, 2003). Online transfer guides have been created to help students, transfer counsellors, and advisers in the transfer process. These guides outline the courses and programs that can be directly transferred for credit between institutions (British Columbia Council on Admissions and Transfer). The Transfer Alberta Guide (Alberta Council on Admissions and Transfer, 2010) is a website that helps students transfer between post-secondary institutions and Ontario has developed common standards for learning expectations that facilitate student transfer (Ontario Ministry of Training, Colleges and Universities, 2010a).

Block transfers allow admission to four-year programs directly without the course-by-course comparisons contained in articulation agreements: this differs from the transfer models practiced in Alberta or British Columbia, where the first two years of college count one-for-one when transferring from college to university. Block transfer compares the outcomes of similar educational programs, removing the need to assess each course of a college program with each course 
of a university program. Block transfers may also eliminate the need to have a formal agreement with each program of each institution, as they may apply to all designated educational programs, regardless of institution. This is particularly important for students applying from geographically disparate colleges, such as in Ontario, where there are 24 colleges for applied arts and technology in over 100 locations (Ontario Ministry of Training, Colleges and Universities, 2009).

\section{Barriers for Transferring Students}

Despite the increased interest in transferring from college to university (CMEC 2009), students face many obstacles. First, transfer policies are often vastly different between schools. This is confusing for students and for academic counsellors whose advice may be wrong, out-of-date, or inconsistent (Andres, 2001). Second, universities may use inconsistent procedures for accepting course credit from other institutions. In both Canada and the United States many universities continue to reject credits from community colleges even though many of the credits earned at community colleges are comparable to those earned at universities (Miller, 2007). This comparison extends past basic course content to the use of the same textbooks, the employment of teaching faculty with similar qualifications, and access to comparable learning resources. Third, even in institutions and regions with strong transfer policies, institutions may employ "transfer-inhibiting" practices. These include enrolment caps that favour current undergraduate students over transfer students, credit-denying practices based on college reputation rather than on official transfer policy, or residency rules that require students to be enrolled for a minimum number of courses or semesters prior to graduation (Moodie, 2007). Lastly, Canadian universities stipulate that all high school students complete a particular number of advanced level high school credits as base requirements for entrance to university programs, but students may attend two- and three-year college programs without them. Universities may require college students who lack the advanced high school credits necessary for admission to replace absent advanced level high school credits, which limits the number of credits available for advanced standing placement in university programs (Bell, 1998). Furthermore, individuals with previously completed college diplomas trying to improve their education by entering university, sometimes learn that they did not take the right college courses and do not receive credit for their previous education (Knoell, 1996; Findlen, 1997/1998).

\section{Improving Transfer Procedures}

Several methods have been used to expedite the transfer process. The Council of Ministries of Education, Canada (CMEC, 2009) is coordinating Canada-wide strategies to improve the transfer process between colleges and universities. The CMEC outlines transfer practices for each jurisdiction, provides feedback reports to the jurisdictions, and rates improvements according to a range that varies from 
modest to significant. This working group has recommended that post-secondary institutions continue their commitment to working together by keeping students informed with up-to-date information about transfer credits and by developing consistent transfer policies.

In British Columbia, the Centre for Curriculum, Transfer and Technology (British Columbia Ministry of Education, Skills, and Training, 1996) facilitated student transitions in order to focus on learning and the needs of learners. This involved coordinating curriculums across colleges and universities that included general and specific skills and knowledge. It also encouraged students to choose learning paths and styles that best met their needs (Bauslaugh, 1992). This approach influenced transfer methods in Alberta (Alberta Council on Admissions and Transfer, 2010) and in other provinces that have instituted educational councils that facilitate communication between institutions and guide the positive evolution of transfer and articulation policies (CMEC, 2009).

Joint admission to community college and university has also been proposed. This allows high school students to begin their post-secondary studies in college and easily move to universities to complete bachelor's degrees (Knoell, 1996; Cohen, 2003, 2005). The Association of Colleges and Universities in Canada (AUCC), which represents 94 Canadian public and private not-for-profit universities and university-degree level colleges, and 175 diploma granting colleges (AUCC, 2009) has provided guides for transfer between member institutions. For example, some community colleges in British Columbia and Nova Scotia combine university and college traditions to offer students both degree programs and college diplomas and certificates, with the latter often "laddering" into the former. The Private Colleges Accreditation Board in Alberta accredits university college courses as equal to university studies. Several university-level colleges in Ontario have recently chosen to adopt the university-college nomenclature to distinguish themselves from community colleges, while some community colleges have received applieddegree-granting powers from the provincial government (AUCC, 2009).

College and university transfer policies in the United States have also focused on easing transfer. Missouri has required all higher education institutions to create a 42-semester-hour block of education credit that is accepted as equivalent across institutions in order to assure portability of general education credit (Coordinating Board for Higher Education, 2009). The Utah State Legislature passed a law requiring the transferability of undergraduate coursework to all public institutions. The Utah System of Higher Education (USHE) also provides a transfer credit guide and links students with transfer credit information at specific institutions (USHE, 2010). The Quality in Undergraduate Education (QUE) initiative articulated competencies in core disciplines that provide standards for credit transfers between community colleges and four-year institutions (Henry, 2006).

California has significantly increased transfers between colleges and universities by developing standardized procedures and support services. The transfer system is characterized by seven factors (Handel, 2007). First, encourage academic 
preparation by setting up useful university preparatory courses that help college students focus on a major at an early stage, rather than simply gaining general college credits. Second, promote better communication regarding transfer procedures, including the positive experiences of transfer, such as, the availability of financial aid and statistics that show that transfer students perform just as well as direct-entry students over four years of study. Third, increase support for community college counsellors to help them attend to students at each stage of the transfer process and offer flexible advising hours (Andres, 2001). Professional development conferences, offering up-to-date information about transfer policies and procedures, need to be made compulsory for all community college and university counsellors (Handel, 2007). Fourth, ask community colleges and universities to adjust their current practices to help most students most of the time by developing a general-education curriculum, approved by all four-year institutions and a database outlining all state and province-wide articulation agreements. Fifth, ensure community college applicants receive priority in the admission process, and sixth, set transfer targets for students from community colleges. This sends the message that transfer is possible and probable for most transferring community college students and creates a 'transfer-going' culture, which is the seventh factor for promoting effective transfer. This culture requires both community colleges and universities to increase the success of transferring students.

The Bologna Declaration committed European universities to creating a student-centred learning process with defined cycles of higher education (European University Association, 2005) and a European Credit Transfer System that uses learning standards associated with these levels to determine a transferrable amount of credit. It also provides annually updated information about curriculum structures, course availability and locations, student accommodations, and registration procedures across European universities (European Commission Education \& Training, 2010). This initiative allows more opportunities for students to complete degree requirements at more than one university. However, it does not resolve questions about differing workload and learning expectations between universities and programs and concerns about courses being used for requirements of two or more degrees at different universities (Dixon, 2009).

While these policies have eased student transfer in some regions, it has been challenging to create standards that describe course credit or program outcomes that match expectations across a wide range of colleges and universities. It is particularly difficult when students seek transfers between institutions of higher education that are in different regions, countries, or educational organizations such as AUCC (Marshall, 2005/2006). Although their degrees are considered acceptable for specific employment purposes, they have diminished value when accessing higher education opportunities at many Canadian universities. These different levels of educational achievement have led universities to examine the transfer student's personal academic performance as well as the quality of the institutions that they attended. It also slows the development of overall Canadian university 
admission policies for transferring students (Marshall, 2005/2006). Increased use of block transfers would implement many of these recommendations. Block transfers would clearly describe college coursework that allows advanced placement in universities, and they would simplify university transfer decisions resulting in a friendlier transfer culture. However, block transfers depend upon accurately comparing the knowledge and skills learned in one program with the knowledge and skills prerequisites for another program. Learning outcomes concepts provide an effective method for defining, measuring, and comparing the knowledge, attitudes, and skills that students exhibit after a learning experience. The following sections describe learning outcomes and propose a learning outcome approach that can further reduce barriers to transfer.

\section{LEARNING OUTCOMES}

Shipley (1994) views learning outcomes as contributing to the move away from teacher-directed learning, based on content. Shipley (1995) defined learning outcomes as "statements which describe the significant, essential, transferable, verifiable learning that must be demonstrated in order to receive credit for a unit of study/course/ program" (p. 16). Harden (2002) describes learning outcomes as "what is achieved and assessed at the end of a course of study" (p. 151). Learning outcomes identify abilities students should be able to demonstrate as a result of a learning experience, including the knowledge, skills, and attitudes that make up the overall integrated learning of a course or program (Daniel \& McInnes, 2007).

Some authors caution that learning outcomes should not be used interchangeably with objectives (Harden, 2002; Shipley, 1994). Harden suggests the extensive detail in the use of objectives obscures the overall intent of the curriculum while user-friendly, transparent learning outcomes make it easier to get agreement in specifying key areas of learning. Learning outcomes therefore focus on students' "internalized, significant applications of knowledge and abilities" (Shipley, 1994, p. 2) while objectives focus on program standards and benchmarks. Learning outcomes have greater impact on student learning, providing a flexible approach to what is to be achieved and assessed. Learning outcomes focus on what a student knows or is able to do following a course compared to the more traditional learning objectives which describe the learning experiences that occur during a course. In contrast to a teacher-centred approach, this learning-centred curriculum approach responds to student learning needs and circumstances (Hubball \& Gold, 2007).

Learning outcomes that state observable and measurable knowledge or abilities (Daniel \& McInnes, 2007) are characterized by action verbs that are associated with levels of knowledge. These actions verbs are evident in Bloom's Taxonomy of Education in undergraduate teaching that outlines the following knowledge categories: knowledge, comprehension, application, analysis, synthesis, and evaluation (Aviles, 2000, 2001a, 2001b). A list of action verbs is assigned to each area of knowledge, as noted in Table 1. 


\section{Table 1}

Bloom's Taxonomy: Knowledge Levels and Corresponding Action Verbs

\begin{tabular}{ll}
\hline Knowledge Level & Action Verbs \\
\hline Knowledge & Define, identify, state, list, differentiate, discriminate \\
Comprehension & Explain, translate, interpret, match, extrapolate \\
Application & Construct, choose, predict, demonstrate \\
Analysis & Distinguish, separate, organize, infer, classify \\
Synthesis & Compose, formulate, create, integrate, produce \\
Evaluation & Debate, judge, critique, assess, compare \\
\hline
\end{tabular}

Note: Adapted from Bloom as cited in Aviles, 2001b

As the expected results of a program, learning outcomes are transferable abilities, applicable to many contexts (Kameoka \& Lister, 1992). Learning outcomes attempt to integrate a mixture of concepts, processes, skills, and behaviours that are dedicated to individual disciplines (Morin, 2001). Factors to consider in planning learning activities need to include the diversity of educational backgrounds, learning styles, and individual needs of learners.

\section{Issues about Learning Outcomes}

Despite increased support for learning outcomes, there are widespread debates in educational institutions about how learning should be measured. Proponents of learning outcomes criticize traditional approaches (Bushy, 1992; O'Banion, 2007) that describe course content but do not measure student learning. Others maintain that learning outcomes attempt to predict a future that may or may not occur and are unable to accurately measure an abstract concept such as learning. Identifying and documenting learning outcomes for educational courses and programs is a challenging task. It is easier to describe the learning in a course than to predict student performance following a course. It requires educators to evaluate different forms of instruction and assessment and challenges students to learn from various teaching and testing methods. Increased time for course design and planning may also be a factor for faculty since developing learning outcomes could result in increased course preparation time at the expense of ensuring increased efficacy in the classroom (Aviles, 2001a). However, as Clark (2002) argues, we cannot rely totally on student reporting in assessing learning outcomes, so it is imperative that instructors aim to find ways to measure long lasting outcomes.

Clark (2002) suggests innovative practices to measure outcomes, such as, determining the impact of instruction after students have left the campus. She clarifies that without knowing what the students' performance is in advance of the instruction, there is no valid way to conclude that the instruction was responsible for the performance. Discerning the student and instruction variables that are responsible for post-course performance would require random assignment to groups, pretesting as well as post testing, and the use of comparison groups. Clark recommends improved methods of research on learning outcomes in determining how the quality of education may improve. 
Hussey \& Smith (2003) emphasize learning outcomes should focus on student engagement, maximizing learning opportunities rather than adhering to pre-specified outcomes. They suggest that instructors who aim to achieve the learning outcomes may minimize potential opportunities that arise for deeper learning. They introduce the idea that broad learning outcomes allow the flexibility necessary for instructors to realistically adapt to other learning outcomes introduced by student motivation. In developing program learning outcomes, Hussey and Smith saw the need to prevent the use of learning outcomes for administrative monitoring and audit purposes, which use outcomes-based research for program evaluation and professional accreditation. However, student learning outcomes defined as "the essential, significant, transferable performances to be achieved by all learners before they receive credit for a course, module or unit of learning" (Shipley, 1994, p. 3), identify criteria for effectively assessing student transfer credits.

Using learning outcomes for program comparison is challenging, influenced by a lack of collaboration among disciplines, ineffective assessment tools, perceptions that some learning outcomes are not measurable, resistance to self-assessment, and increasing demands because of constrained resources (Miles \& Wilson, 2004). These drawbacks prevent many from applying learning outcomes in higher education. In changing curricula from focusing on instruction to providing learning-centred environments, Warren (2003) focuses on accountability, assessment, and outcomes. Warren views the increasing demand and institutional mandate for learning outcomes as an evolving process that requires "time, effort, and the cooperation of instructors, administrators, students, and other stakeholders in educational systems" (p. 728-729).

\section{Using Learning Outcomes in Colleges and Universities}

Focusing on developing curriculum and assessing the level of student learning rather than assessing the effectiveness of college and university education, learning outcomes provide a means for comparing diverse methods of instruction in higher education. While all educational programs attempt to increase knowledge and skill development, college programs often focus on skills acquisition learned through laboratory or field experiences. University programs often emphasize theoretical and research knowledge. Although this balance between knowledgeand skill-based methods can be very different between educational institutions and programs of study, the intended outcome of educational curricula is often similar. In addition, diverse student learning needs are encouraging educators to use a mixture of instructional methods and styles in order to assure successful learning. This increases instructional compatibility between colleges and universities. A variety of teaching tools, such as lecture presentation, guided student discussions, group work, student self-reflection, lab work demonstrating skills, and student presentations, can bridge gaps in previous learning, inspire learning, and provide parallel learning experiences that promote professional skills and at- 
tributes. Learning outcomes can also simplify comparisons between educational programs since they are able to define learning across multiple courses using diverse instructional methods rather than rely upon matching individual courses within programs.

According to Hubball and Gold (2007), learning centredness promotes equity in access and learning styles, an objective that has failed in traditional approaches. According to Carducci's (2006) bibliographic review of American community colleges, application of learning outcomes promoted active learning practices, such as team work, collaboration, and self-reflection. This is similar to the self-directed nature of adult learning theory, which conceptualizes the use of multiple teaching tools, referred to as andragogical instruction. Carducci reminds us that Knowles theory of andragogical instruction "asserts traditional pedagogical instruction presents as a problem for non-traditional students" (p.281) who may lack knowledge of theoretical concepts that are foundational to the instruction or may be more familiar with hands-on learning styles. Adult learning theory suggests that students in higher education are adult learners who define themselves by their experiences (Bushy, 1992). They are more likely to relate in-class learning with practical experiences outside class and seek to apply knowledge to useful skill sets. Educational experiences that amplify this knowledge transfer may increase successful learning. Learning outcomes that identify student levels of competence, irrespective of instructional method, can measure a broad range of educational experience and provide acceptable criteria for curriculum comparisons.

Learning outcomes can also describe the progressive nature of learning experiences, which is particularly applicable to students transferring for advanced educational opportunities. Currently, college and university courses often require prerequisite courses that assure that students have prior knowledge or skill. This policy is often dependent upon the content presented in specific courses, and it assumes that students who have completed certain courses have attained a level of competence. Learning outcomes explicitly define the student's competence rather than the course content and can measure competence level across a broad range of learning experiences. Student progress can be defined, in all educational programs, when learning outcomes are identified at each stage of a course of study. This creates a method for matching competence levels across programs. It is based on student achievement rather than specific course content or instructional methods, and it can eliminate barriers to the transfer process from college to university.

In addition, learning outcomes communicate clear expectations to learners, instructors and prospective employers regarding student learning experiences. This facilitates course content, preparation, and assessment that acknowledge various student learning needs. It documents educational program outcomes which can assist accreditation and student transfer between programs. It assures students and employers that specified learning has been accomplished. It encourages accountability, student success, and consumer protection. 


\section{Learning Outcomes in Easing Transfers}

The use of learning outcomes by colleges and universities fosters a smoother transition from college to university and is better able to meet the diverse needs and circumstances of students (Hubball, Gold, Mighty, \& Britnell, 2007). Learning outcomes allow educational institutions to compare their programs. For faculty and other university program stakeholders, learning outcomes facilitate the development of an objective benchmark for a formative, summative, and priorlearning assessment of students (Hubball et al., 2007). Learning outcomes facilitate the comparison of students and contribute to a systematic method of identifying specific needs for certain groups of students. Learning outcomes also guide assessment and evaluation and encourage accountability, since curriculum effectiveness is based on student acquisition of knowledge and skills. This provides checks and balances for the transfer process since both colleges and universities assume responsibility for demonstrating the learning outcomes at each step of an educational program.

Canadian literature on community college and university use of learning outcomes is scarce. However, the concept of learning outcomes has been widely discussed throughout the educational system across the country, and the government bodies responsible for education in various provinces have approved the use of learning outcomes. General and specific outcomes resulted when the administration in a school division in Manitoba mandated learning outcomes for the grade K-6 curriculum for music teachers as a way of conducting assessment and evaluation practice (Morin, 2001). The ensuing learning outcomes resulted in an integration of ideas, skills, and behaviours which were unique to the discipline of music. Developments that focused on the use of learning outcomes at the college and university level include Bauslaugh's (1992) proposal that the first two years of post secondary education would be years of general education and that last two would consist of specialization. These recommendations supported strategic changes in British Columbia (British Columbia Ministry of Education, Skills, and Training, 1996). The Ontario Ministry of Training, Colleges and Universities (2010b) has promoted learning outcomes as a basis to establish program standards for similar provincial college programs based on Shipley's $(1994,1995)$ views that emphasize the accountability, equity, access, and quality produced by learning outcomes. These initiatives represent efforts to improve the ability to compare learning between college programs and university programs, which potentially eases transfer for students seeking advanced educational degrees.

It makes sense to focus on learning outcomes as a flexible means for facilitating student transitions and lifelong learning. Program learning outcomes address cumbersome transfer methods that involve lengthy course-by-course comparisons and numerous, complicated articulation agreements, necessitating extensive investments of time for faculty. Standardized learning outcomes make it easier for faculty and students at colleges and universities to evaluate programs, enhanc- 
ing student recruitment and engagement. Standardized learning outcomes, as a resolution to transfer issues, is supported by the programs established in British Columbia, Alberta, Utah, Missouri, and Europe, and evident in California's system for improving transfers (Handel, 2007). These systems have focused on block transfers defined by learning outcomes for simplifying the cumbersome aspects of individual course comparisons and program articulation agreements.

\section{Transfer as a Collaborative Strategy}

Learning outcomes do provide a promising method for comparing educational outcomes that can improve student transfers between educational institutions. Hubball and Gold (2007) suggest that increasing the transferability of learning encompasses the Scholarship of Curriculum Practice (SoCP). Under this model, multiple parties act collaboratively and make the alignment of curriculums a priority. In the practice of SoCP, instructors employ multiple teaching methods - such as mastery learning, group work, self-directed learning, lectures, and learning papers - progressively and consistently throughout educational subsystems. Crucial to the success of this model is the provision of professional development about these teaching tools.

Many higher education institutions have begun to collectively establish a system of learning outcomes and initiate collaborative research on student learning and program outcomes. Learning outcome projects need coordinators, teams, coalitions, and task forces in the identification, development, and evaluation of learning outcomes (Hendriksen, Yang, Love, \& Hall, 2005; Hubball, Gold, Mighty, \& Britnell, 2007; Miles and Wilson, 2004). To be successful, these programs must be supported by a range of educational personnel. Administrators and faculty deans, for instance, play an important role in assessing needs, promoting change timelines, and providing training. Department heads and faculty lead efforts to identify realistic and measureable educational outcomes for individual courses and programs (Andrews, 2000). These outcomes may require lab work, internships, portfolio development, or residency requirements. Clearly stating these elements at progressive stages of educational programs improves student transfers since expectations at a broad range of colleges and universities can consider essential elements of diverse educational paths. This process requires combining models of learning used at colleges and universities, as well as establishing a collaborative inter-institutional focus that would involve a team approach and professional development for faculty.

Consistent and mutually supportive provincial guidelines, admissions criteria, and curriculum development policies would also enhance the transfer process. This process has a number of benefits. Students have increased educational opportunities; learning outcomes are more clearly described; collaborations between educational institutions can reduce duplication and increase flexibility; and simplified transfer procedures can reduce assessment time for university registrar 
personnel and help students plan advanced educational opportunities. These benefits encourage a transfer-friendly culture that promotes successful outcomes for universities, colleges, and students.

\section{CONCLUSION}

In order to achieve the above goals of an improved transfer process, it is necessary to consider the practical application of such a process. The idea of assessing learning outcomes is one that needs to be largely under the purview of the academic disciplines involved. In order to make such a process effective, this often requires consideration of the individual student's progress, achievement level, and specific course selection within programs of study. On the other hand, personnel responsible for admission and registration, along with individuals undertaking recruitment and public relations, need to be able to make clear statements about what perspective students can anticipate receiving in the way of transfer credit. This not only allows these individuals to do their jobs more effectively, but also allows students to plan their education path effectively.

The current system of student transfer between Canadian institutions of higher learning is inconsistent, often cumbersome, and challenging for students. Standardized criteria and block transfer methods have eased transfer procedures in American and European colleges and universities, and they have improved transfer processes in British Columbia and Alberta (Alberta Council on Admissions and Transfer, 2010; British Columbia Council on Admissions and Transfer, 2003). The Council of Education Ministries, Canada (2009) advocate further changes in all provinces. This process would involve the blending of block transfer credits and degree completion specifications. In such a process, the colleges and universities (hopefully on a province- or state-wide basis) would collaborate to establish an agreed level of entry into university degree programs from particular college programs. Provincial and professional accreditation processes, which often include learning outcomes, could also support block transfers.

Specified learning outcomes for each course and program of study would provide a more measurable, authentic, and collaborative approach for comparing student experiences. Learning outcomes focus on the knowledge, attitudes, and skills that students achieve at each stage of learning in higher education rather than the diverse contexts and various teaching and learning methods that accomplished the learning. This facilitates transfer between institutions or courses of study. For example, a student receiving a diploma in Early Childhood Education might demonstrate the learning outcomes necessary to enter any degree program in Arts or Social Sciences at the second year level. This would provide the equivalent of 10 one-semester courses (one year), but rather than assessing what courses were being credited, each degree program would specify what courses must yet be taken to achieve degree completion. 
Where student-learning outcomes indicated that a student had already achieved the outcomes of a course included in the degree completion requirements, an equivalency could be granted and this course replaced with a different course at a comparable level. No change, in the transfer credit value of the original block, would occur. In this way, there would be allowance for assessment of individual student outcomes, without complicating the overall transfer credit process.

Learning outcomes measures potentially reduce inconsistent methods for comparing courses and programs and evaluate the current competence of students instead of focusing on specific courses completed in secondary or post-secondary institutions or heterogeneous instructional methods. They challenge each institution and educational program to describe expected student achievement at each stage of learning. In addition to the required knowledge, attitudes or values, and skills, this could include residency or time periods and methods for demonstrating competence. Learning outcomes describe accomplishments rather than judge adequacy. They encourage institutions to collaborate. Institutions that provide basic education are better able to predict educational outcomes needed by advanced programs, and advanced programs can adjust requirements to welcome students from diverse learning backgrounds. These methods ease transfers which benefits students and institutions. Students are able to choose educational paths that best meet their needs and post-secondary institutions are able to market instructional programs that assure the acquisition of essential knowledge and skills without sacrificing flexibility.

\section{REFERENCES}

Alberta Council on Admissions and Transfer. (2010). TransferAlberta. Alberta Learning Information Service. Retrieved from http:/ / alis.alberta.ca/ps/ep/aas/ ta/transferalberta.html

Andres, L. (2001). Transfer from college to university: Perspectives and experiences of British Columbia students. Canadian Journal of Higher Education, 31(1), 35-74.

Andrews, H. A. (2000). The Dean and the faculty. New Directions for Community Colleges, 109, 19-26.

Association of Universities and Colleges of Canada (AUCC) (2009). Retrieved from http:/ / www.aucc.ca/about_us/index_e.html

Aviles, C. B. (2000). Teaching and testing for critical thinking with Bloom's taxonomy of educational objectives. (ERIC Document Reproduction Service No. ED446023)

Aviles, C. (2001a). A study of mastery learning versus non mastery learning instruction in an undergraduate social work policy class. (ERIC Document Reproduction Service No. ED449413)

Aviles, C. (2001b). Creatively adapting mastery learning and outcome-based education to the social work classroom. Paper presented at the Joint Conference of the International Federation of Social Workers and International Association of Schools of Social Work, Montreal, QC. (ERIC Document Reproduction Service No. ED449414) 
Bauslaugh, G. (1992). Undergraduate education in British Columbia: Choices for the future. British Columbia Ministry of Advanced Education, Training and Technology, Victoria, BC. (ERIC Document Reproduction Service No. ED350912)

Bell, S. (1998). College transfer students: A Canadian case. College Journal of Research and Practice, 22(1), 21-37.

British Columbia Council on Admissions and Transfer. (2003). Provincial postsecondary systems and arrangements for credit transfer. [Report]. Vancouver, BC: Author. Retrieved from http: / / www.cmec.ca/ postsec/CreditTransfer.en.pdf

British Columbia Ministry of Education, Skills, and Training. (1996). Charting a New Course: A Strategic Plan for the Future of British Columbia's College, Institute and Agency System. Victoria, BC: Author.

Bushy, A. (1992). Adult learners: considerations for counsellors in the educator role. Guidance \& Counselling, 8(1), 6-14.

Carducci, R. (2006). UCLA college annotated bibliography: The application of learning theories in college classrooms. College Journal of Research and Practice, 30(3), 279-285.

Clark, R. A. (2002). Learning outcomes: The bottom line. Communication Education, 51(4), 396-404.

Cohen, A. M. (2003). The community colleges and the path to the baccalaureate. Paper prepared for the Center for Studies in Higher Education Research Paper Series. (ERIC Document Reproduction Service No. 476338)

Cohen, A. M. (2005). The future of transfer. Journal of Applied Research in the College, 12(2), 85-91.

Coordinating Board for Higher Education. (2009). Credit transfer guidelines for student transfer and articulation among MO colleges and universities. Retrieved from http:/ / www.dhe.mo.gov/ credittransfer.shtml

Council of Ministries of Education, Canada. (2009). Report of the CMEC Working Group on Credit Transfer. Retrieved from http: / / www.cmec.ca/ Publications / Attachments / 217 / credit-transfer-group-report-2009.pdf

Daniel, Y., \& McInnes, A. (2007). Learning outcomes: Teaching with the "end" in mind. Workshop presentation at the University of Windsor. Retrieved from http: / / apps.medialab.uwindsor.ca/ctl/ downloads/2007/Daniel McInnes.pdf

Decock H. (2004). Calculating the college-to-university transfer rate in Ontario. College Quarterly, 7 (1). (ERIC Document Reproduction Service No. EJ852024)

Dixon, J. M. (2009, March 19-20). Understanding implications - A Canadian perspective. Panel discussion presented at the University of Alberta Conference: Canadian perspectives on the Bologna Process in Edmonton, AB.

European Commission Education \& Training. (2010). European credit transfer and accumulation system (ECTS). Retrieved from http:/ / ec.europa.eu/education/ lifelong-learning-policy/doc48_en.htm 
European University Association. (2005). Trends V: Universities shaping the European higher education area. Retrieved from http:/ / www.sowi-due.de/uploads/108.pdf

Findlen, G. L. (1997/1998). Technical colleges and college transfer: One more time. American Technical Education Association Journal, 25(2), 4-7.

Handel, S. J. (2007). Second chance, not second class: A blueprint for college transfer. Change, 39(5), 38-46.

Harden, R.M. (2002). Learning outcomes and instructional objectives: Is there a difference? Medical Teacher, 24, (2), 151-155.

Hendriksen, S. I., Yang, L., Love, B., \& Hall, M. C. (2005). Assessing academic support: The effects of tutoring on student learning outcomes. Journal of College Reading and Learning, 35(2), 56-65.

Henry R. (2006). Faculty development for student achievement: The QUE project. Bolton, MA: Anker.

Hubball, H., \& Gold, N. (2007). The scholarship of curriculum practice and undergraduate reform: Integrating theory into practice. New Directions for Teaching and Learning, 112, 514.

Hubball, H., Gold, N., Mighty, J., \& Britnell, (2007). Supporting the implementation of externally generated learning outcomes and learning-centered curriculum development: An integrated framework. New Directions for Teaching and Learning, 112, 93-105.

Hussey, T., \& Smith, P. (2003). The uses of learning outcomes. Teaching in Higher Education, 8, (3), 357-368.

Kameoka, V. A., \& Lister, L. (1991). Evaluation of student learning outcomes in MSW programs. Journal of Social Work Education, 27(3), 251-257.

Knoell, D. M. (1996). Moving towards collaboration in transfer and articulation. New Direction for Colleges, 24 (4),55-64.

Marshall, D. (2005/2006). What's it worth?: The tiering of Canadian degrees. Education Canada, 46(1), 55-57.

Miles, C. L., \& Wilson, C. (2004). Learning outcomes for the twenty-first century: Cultivating student success for college and the knowledge economy. New Directions for Colleges, 126, 87-100.

Miller, H. N. (2007). Legislation can end bias against career colleges. The Chronicle of Higher Education, 53(48) B8.

Moodie, G. (2007). Do tiers affect student transfer? Examining the student admission ration. College Journal of Research and Practice, 31(11), 847-861.

Morin, F. (2001). General and specific outcomes for grade one to five music. Prepared for Transcona-Springfield School Division No. 12. (ERIC Document Reproduction Service No. ED465694)

O'Banion, T. (2007). Creating a new architecture for the learning college. Community College Journal of Research and Practice, 31(9), 713-724. 
Ontario Ministry of Training, Colleges and Universities. (2009). About Ontario Colleges. Retrieved from http://www.edu.gov.on.ca/eng/general/postsec/college.html

Ontario Ministry of Training, Colleges and Universities. (2010a). Ontario Qualifications Framework. Retrieved from http://www.edu.gov.on.ca/eng/general/ postsec/oqf.html

Ontario Ministry of Training, Colleges and Universities. (2010b). Published College Program Standards. Retrieved from http:/ / www.edu.gov.on.ca/eng/general/ college/progstan/index.html

Shipley, C. D. (1994). Learning outcomes: Another bandwagon or a strategic instrument of reform? (ERIC Document Reproduction Service No. ED 375876)

Shipley, D. (1995, Oct. 27). Transforming community colleges using a learning outcomes approach. Workshop sponsored by Advanced Education Council of British Columbia \& the Centre for Curriculum \& Professional Development in Richmond, BC. (ERIC Document Reproduction Service No. 388346)

Student Transitions Project. (2008). Research results from the Student Transition Project. British Columbia Ministry of Advanced Education and Labour Market Development. Retrieved from http:/ / www.aved.gov.bc.ca/student_transitions / documents /stp_highlights_nov08.pdf

Thompson, S. (2003). Collaboration for student success: A system for providing transfer student performance information to feeder institutions. Paper presented at the Association for Institutional Research Annual Forum, Tampa, FL. (ERIC Document Reproduction Service No. ED477826)

Utah System of Higher Education. (2010). USHE Transfer Credit Guide. Retrieved from http:/ / www.utahsbr.edu/acad01c.html\#USHETCG

Warren, J. (2003). Changing community and technical college curricula to a learning outcomes approach. Community College Journal of Research and Practice, 27, 721-730.

\section{CONTACT INFORMATION}

Irene Carter

School of Social Work

University of Windsor

401 Sunset Avenue

Windsor, Ontario N9B 3P4

Telephone: 519-253-3000 (ext. 3079)

Fax: 519-973-7036

icarter@uwindsor.ca

Irene Carter is an Associate Professor, School of Social Work, University of Windsor. Developmental and intellectual disabilities, self-help groups, disability studies, and continuing professional education are Irene's main areas of research in- 
terest. Irene has 25 years of experience that includes program development for persons with disabilities. She played an integral role in the implementation of the Interdisciplinary Honours Disability Studies Program, University of Windsor, developing courses for the program and serving as its first coordinator. Irene's work is reflected in her scholarly pursuits are inspired by her teaching and her commitment to professional education.

James P. Coyle is an Assistant Professor in the School of Social Work at the University of Windsor. He teaches undergraduate and graduate students about social work practice skills using examples from twenty years as a social work practitioner in child welfare, mental health, and family services agencies. His current research examines the nature of resilience in families affected by chronic or acute adversity, the impact of community resilience factors on families and individuals, and interventions that improve community and family resilience. In addition, he is also studying social workers' professional writing skills.

Donald R. Leslie is a Professor at the School of Social Work, University of Windsor. He has taught social work, been a practitioner, and a social service administrator for the past 40 years in Canada, the United States and Australia. His specialty areas are work with families and the physically disabled, consultation and research with non-profit boards, program and organization evaluation, and organization management. He was instrumental in developing the Interdisciplinary Honours BA degree program in Disability Studies. He has published technical reports, monographs, chapters, articles and case studies. 